\title{
Childrearing and the Shaping of Children's Emotional Experiences and Expressions in Two Argentinian Communities
}

\author{
CAROLINA REMORINI \\ National University of La Plata, Argentina
}

\begin{abstract}
This article analyzes the role of children's social environment in shaping children's emotional expressions. It is based on the findings of an ongoing research study interrogating childrearing practices in two rural populations representing two contrasting ecological contexts in Argentina: Mbya Guarani indigenous communities located in the northeast rainforest (Misiones Province) and creole communities from Molinos (Salta Province), in the highlands and semiarid areas of Argentinean northwest. The focus of this article is on the ways in which adults interpret and respond to children's crying as one manifestation of emotional behavior. This article attempts a comparative analysis of representations, attitudes and behaviors regarding children's crying. It is stressed how discourses of childhood validate some expressions of emotion and restrict and pathologize others. On one hand, parents from both populations not only differ in their tolerance of children's crying but also differ in their evaluation of the difficulties of rearing 'weeping' children. On the other hand, in both populations excessive senseless crying represents a risk for children's health as it is considered a symptom of several illnesses. Based on these considerations, at the end of this article each population's ethnotheories of children's appropriate emotional behavior is analyzed, and the implications of these ethnotheories for emotion socialization.
\end{abstract}

\section{Introduction}

The ways in which emotion is manifested and responded to in different cultures has been a classic issue in anthropology since its origins. The pioneering research of Margaret Mead (1954, 1962, 1990) Gregory Bateson (Bateson \& Mead, 1942), and David Efron (1972) regarding gestures and the concept of 'body technique' proposed by Marcel Mauss $(1921,1971)$ also contributed to the ongoing debate about the interaction among physiological, anatomical, psychological, sociocultural and historical variables into corporality, gestures and expressions of emotion, emphasizing the patterns and techniques guiding their education and learning. These authors provide specific examples of the value of culture in shaping emotions and actions that demonstrate a supportive or non-supportive response to children's emotional expressions. Therefore, the consideration of the 'homme total' (Mauss, 1971) implies the need to study corporality and emotional behavior from a holistic and interdisciplinary perspective.

Considering that socialization of emotions unfolds in daily life as children learn different ways of expressing and understanding emotions in their relationships in the domestic context, in this article I analyze the role of children's social environment in shaping children's emotional expressions. This article is based on the findings of an ongoing ethnographic research on child development and rearing practices in two rural populations representing two contrasting ecological contexts in Argentina. The research team focused on the ethnographic observation of rearing practices and interviewed parents and other caregivers to uncover their judgement of their own 
child's behavior in relation to wider ethnotheories (Harkness \& Super, 1986; Cervera \& Méndez, 2006) about child development and healthy behavior.

For the purpose of this article, I am mainly interested in crying as a manifestation of emotion that reflects different attitudes of children's social environment. I attempt a comparative analysis of representations, attitudes and behaviors regarding children's crying. Taking into account ethnotheories of children's appropriate behavior in each population, I try to link these representations with parenting goals and with parents' wider beliefs and values about personhood, growth, health and children's sociability in both ecological contexts. I stress how discourses of childhood validate some expressions of emotion and restrict and pathologize others.

\section{Childrearing and the Shaping of Emotions from AN Ecological Perspective}

A review of ethnographic and cross-cultural studies on childrearing shows that there are attitudes and practices that restrict or encourage emotional expressions, gestures and body movement and also stress that learning the correct and effective use of the body (Mauss, 1971) is a central component of socialization from an early stage of life. These practices and attitudes are justified in ideas and cultural values about child growth and development and gender differences. They are also based on cultural values that express what is expected of members of society at every stage of the life course. Studies within 'Culture and Personality' are representative in this sense.

As Gauvain (1998, p. 188) states:

In all societies throughout the world, most children grow up to be competent members of their communities. This impressive phenomenon ... relies on some inherent human ability to develop intellectual and social skills adapted to the circumstances in which growth occurs and ... cultural desired patterns of development.

Parents guide their actions with their children in accordance to their cultural constructions of childhood; thus, they tend to reproduce culturally accepted behavioral phenotypes through the structuring of the developmental niche (Harkness \& Super, 1986; Cervera \& Méndez, 2006).

According to Cervera and Méndez (2006) research on culture provides an understanding of emotional behavior in the context of the childrearing environment and its cultural structuring. Culture, specifically parents' ethnotheories and rearing practices, is seen as the principal organizer of individual variability. At the same time it is also important to recognize 'the role played by children in shaping their environment' (Cervera \& Méndez, 2006, p. 328). In this sense, as children are equipped to participate in the sharing of meanings (Rogoff et al, 2003) parental beliefs and actions serve to mediate children and culture by communicating affective, didactic messages about how behaviors are conceptualized and valued in everyday interactions (Harkness \& Super, 1986; Cervera \& Méndez, 2006).

In recent decades there has been substantial progress in the cultural study of Early Childhood Development (ECD). Several authors acknowledge the contribution of anthropology to the debate about ECD, in dialogue with psychology, neuroscience, education and medicine (Weisner, 1996). These studies stress the importance of the social contexts with regard to physical growth and later health issues. In other words, anthropology emphasizes the notion that development of children's emotional, cognitive and social abilities is driven by the interactions that children have with those in their immediate and intimate environments.

In this sense, the importance given to the environment from an ecological perspective (Bronfenbrenner, 1987) recognises the heuristic value of ethnographic studies. Ethnography, as the study of contemporary lifestyles, and the characteristics of its methodology allows us to approach aspects of parenting and child development that are not easily accessible by other methodological approaches. The central aim of ethnographic research is to describe and understand the environment or 'scenarios' that influence children's trajectories and everyday life, together with tools and resources that children use to develop in the environment (Weisner, 1996; Remorini, 2009).

Based on the above-mentioned ideas, eco-cultural or ecological approaches (Whiting \& Whiting, 1975; Weisner, 1984, 1996; Bronfenbrenner, 1987) understand development as an adaptation to different ecological conditions, i.e. various 'developmental niches' (Weisner, 1984; Harkness \& Super, 1986). Within the developmental niche, Harkness and Super (1994) have 
assigned parental ethnotheories the leading role in shaping and organizing children's physical and social settings. What Harkness and Super (1986) called 'parental ethnotheories' are specific cultural models, rooted in the collective history of the community, that provide a framework for adults to build experience and knowledge that guide their rearing practices. From these ethnotheories, certain children's behaviors, skills, ways of knowing and expression are privileged (Cervera \& Méndez, 2006).

In this sense, childrearing refers to the 'construction of person' according to the values of society and can be thought as a 'cultural project.' As Greenfield et al point out:

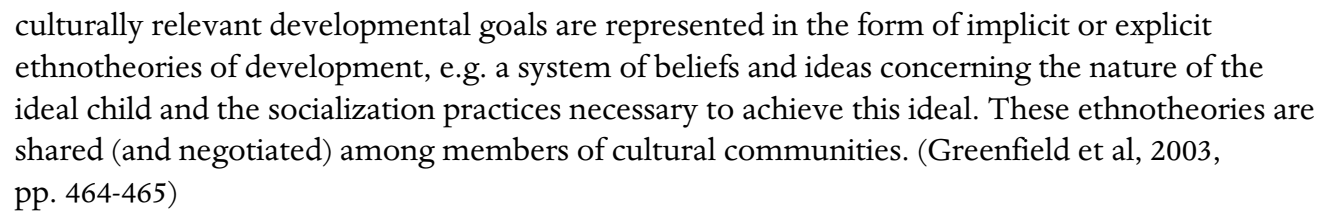

Cultural ideas and values define a kind of person the society promotes. But unlike the classic theories of socialization, recent approaches have highlighted that children have an enormous capacity for selection and transformation, so the results are not homogeneous. As Ingold (2000, pp. 11, 86) pointed out, what parents provide are 'the developmental conditions under which growth to maturity can occur ... but [children] are not "made" through socialisation.' In line with these arguments, parenting can be considered a sociocultural process, bidirectional and interactive, historically anchored (Elder, 1998) and enacted in a specific ecological context (Harkness \& Super, 1986; Bronfenbrenner, 1987; Weisner, 1996).

\section{Methodology}

The subject of this article is part of an ethnographic research that investigates representations and daily rearing practices and their relation to child development from an ecological perspective. This research is carried out in rural populations representing two contrasting ecological contexts. One of them is an indigenous population (Mbya Guarani) located in the northeast rainforest of Argentina (Misiones Province). The other is a creole population located in Molinos (Salta Province), in the highlands and semi-arid areas in the Argentinian northwest, exhibiting a mixture of indigenous and hispanic elements. The information presented here comes primarily from fieldwork conducted between 2001 and 2008 in Mbya communities and fieldwork carried out between 2009 and 2011 in different areas of Molinos.

From the methodological point of view, this research was based on the combination and complementary use of qualitative techniques, giving special emphasis to ethnographic observation of childrearing practices and children's daily activities in the domestic scope.

As Solis-Cámara and Romero (2007) highlighted, studies about parents' beliefs involved in childrearing have been developed in parallel, rather than convergently with studies about practices. As a consequence, there are few observational studies, and the majority are based on verbal reports. Frequently, psychology and sociology studies focus on 'parenting styles' defined as parents' general attitudes or beliefs about their own children's upbringing. In contrast, parenting practices relate to parents' specific behaviors designed to guide children towards achieving explicit goals of socialization (Solis-Cámara \& Romero, 2007, p. 177).

The current work emphasizes the heuristic potential of systematic observation of the child's everyday life as the most important technique to inform what it means to be a child in each ecological context and to characterize everyday experiences with an impact on their growth, development and health. Likewise, observation allows the researcher to account for children's agency in their own development and also shows intra/intercultural variability around these aspects (Remorini, 2010).

In Mbya communities during successive fieldwork the research team used systematic ethnographic observation at fixed intervals, spot observations, day of life and participant observations. They were made in two stages. The first one consisted of long observations (in terms of Daltabuit Godás, 1992) in five households, some from each community, covering most of the day ( $8 \mathrm{am}$ to $7 \mathrm{pm}$ ), for 10 consecutive days. As long as it was possible, we also accompanied people during their everyday itineraries. It allowed us to characterize routine activities of each household 
member. In a second stage we performed two-hour observations in a wide number of households $(n=9)$, but this time focusing on children's behavior and their interactions with other children and adults. Participant observations and spot observations were also made.

Despite our emphasis on observation, people's knowledge and categories are necessary to understand the activities and behaviors being observed. If not, we accord with Gaskings, that it could 'put researchers at risk of importing cultural bias as to their understanding of what children's activities [and, in our case, behaviors and emotions] are most important to ... adults who care for them' (Gaskings, 2000, pp. 376-377). Taking this into account and based on observation results, we interviewed caregivers (parents, grandparents or other individuals) and local experts of both sex ( $n$ $=16$ ) with the aim to deepen our understanding of both groups' beliefs and values in relation to children's behavior and temperament, development, childcare and childrearing. In this sense our purpose was to recognize 'parental ethnotheories' (Harkness \& Super, 1986), as defined previously. Our choice of different-age individuals (between 23 and 75 years old) allowed us to assess similarities and differences among generations. As a result, we obtained 286 observation hours and 25 hours of interviews.

Based on findings of the ethnographic research mentioned above, in 2009 we widened our study to rural populations of Molinos Department. Up to 2011, we conducted two-hour observations in five households, conducted 21 interviews with women [1] between 17 and 73 years old, and obtained 27 hours of verbal record, 57 hours of observational record and five hours of videotapes. In both settings observations and interviews were complemented by photographs and video record.

\section{Results}

\section{Mbya Guarani Communities from Northeastern Rainforest}

The two Mbya Guarani communities are located in a reservation between Cainguas and Libertador General San Martín departments, Misiones Province (Northeastern Argentina) (Figure 1). The Mbya, together with the Kayova, the Nandeva and the Ava Guarani or 'Chiriguanos,' are the Guarani groups with the largest number of members. They speak the languages belonging to the Tupí-Guaraní linguistic family. According to recent estimations the total number of Mbya in Brazil, Paraguay and Argentina adds up to about 19,200 individuals (de Assis \& Garlet, 2004).

In Argentina there exist around 3975 people who identify themselves as belonging to the Mbya people (Instituto Nacional de Estadística y Censos, n.d.). The Mbya presence in Misiones Province dates back to the end of the nineteenth or beginning of the twentieth century when they began migrating outward from the midsouthern region of the forest in modern day Paraguay (Remorini, 2001).

The Mbya inhabit the Paranaense rainforest. Mbya culture has been characterized by their constant spatial mobility as they exploit forest resources and search for areas having favorable conditions for Mbya reko, that is, the Mbya way of life. Although they keep a wide variety of relationships with other people (at local, regional and international levels) Mbya people are acknowledged for their deep relationship with the forest ('monte') and emphasize the historical continuity of their indigenous identity. At present, they still perform their 'traditional' subsistence activities based on the exploitation of natural resources of the forest (hunting, gathering, 'slash-and burn' horticulture, fishing) but with less intensity compared with the past. Handicraft selling and temporary paid jobs in 'colonias' (rural settlements devoted to the production of yerba mate, tea, tobacco and tung [2]) contribute to the maintenance of most households. Some individuals receive allowances and some others get a salary from being teaching assistants or sanitary agents.

The family organization is based on the patrilocal extended family, although uxorilocality and neolocality are also common. Most of the houses inhabited by members of an extended family are located close in space or sometimes around the same courtyard. This spatial arrangement results in the three generations often sharing household chores and grandparents having an important role in childrearing.

Children under one year old are cared for by their mothers and they spend most of the time with them. From the Mbya perspective children are considered vulnerable to different illnesses, and therefore should stay in the house most of the time and avoid certain places full of 'bad spirits' 
that might cause eventual harm. Once they start walking, their social interactions and mobility are widened considerably.

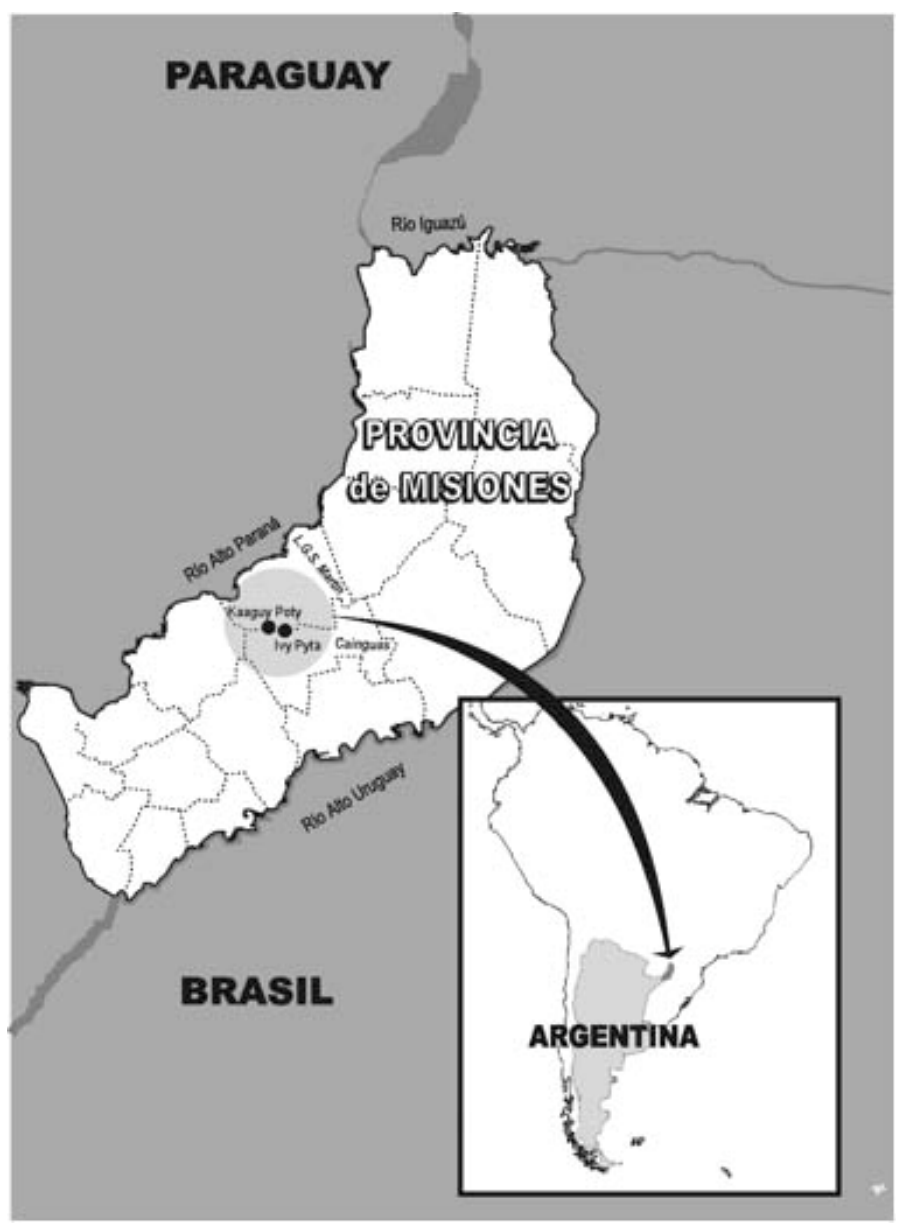

Figure 1. Mbya communities (Misiones province).

Childrearing is shared among members of the household, being grandmothers, mothers and other children who carry out these tasks most frequently. Boys older than two deepen their relationships with their fathers and other male relatives and share with them various activities. However, girls stay close to their female relatives, learning domestic tasks at an early age. In conclusion, children and adults are together in most daily activities (Remorini, 2009).

In spite of having access to biomedical institutions, in each Mbya community there is a diversity of specialists in healthcare. 'Karai' is the term used to refer to prestigious people within a community who have displayed extensive knowledge not only of natural remedies, but also of the prayers and other rituals associated with treatment of illness. Some of these are also recognized as religious leaders and called 'Opyguã'. Unlike other specialists, Opyguã perform ceremonies related to natural and human life cycles (Martínez et al, 2002). A vast number of children's illnesses, such as those referred to in this article, are diagnosed and treated by these specialists.

\section{Mbya Parents' Attitudes toward Children's Crying}

In Mbya communities a crying baby normally doesn't upset adults or children. We have recorded no verbal or gestural expressions of disgust or annoyance when the children cry, even for several minutes. If it's a baby, parents and older siblings try to calm them via verbal expressions of affection as well as with hugs, kisses and caresses. Infants are breastfed on demand in response to any sign of distress and mothers try to keep the child calm, quiet, and happy. A mother will hold and 
breastfeed her child until it calms down, when, for example, one of its brothers takes something from it or hurts it. Another response to the crying child is to provide an object to play with.

Mbya parents' behavior differs when it is an infant or an older child crying (from three or older). In this respect, small children are not left crying for a long time. On the contrary, mothers leave older ones crying for several minutes without offering comfort if they consider them to be 'chinchudos' (angry). If a baby cries because she wants an object that is being used by an older child, the older child is usually ordered to give it to the baby. This demand often leads to the older child's anger causing them to cry, without making parents hesitate to meet the youngest child's needs. In this sense, children who are still not able to speak, nevertheless express their desires and purposes mainly through body movements, gestures and vocal expressions (Malinowski, 1964). Caregivers 'read' in the children's attitudes and movements a message that can trigger different actions.

However, as mentioned before, parents believe that it is not good for children to cry a lot and become disobedient, naughty and irritable. Children who behave in this way are considered to be dominated by a supernatural entity called 'Mba'e Pochy' (meaning, what is bad).[3] Only after the name-giving ceremony - also called baptism [4] - does the child begin to be educated in 'pochy' (anger) control and parents no longer accept crying without any reason (see Larricq, 1993; Cadogan, 1997). When the child is baptized - usually after one year old - they will no longer be dominated by anger. As Cadogan states, 'they will stop rebelling,' their soul 'will be comfortable on Earth' and they 'will be happy' (Cadogan, 1997, p. 71). Based on these beliefs, parents constantly speak to their children, emphasizing that senseless crying is not an appropriate behavior for their age ('na nde pochy': don't be a bad, angry person).

\section{Mbya Ethnotheories about Children's Crying and Vulnerability}

In the Mbya language, child development is known as 'kakuaa,' that is, 'to grow.' It is viewed as a process that involves a set of physical achievements together with the development of social skills and habits associated with an idea of a person rooted in the culture. The expression 'mit $\tilde{a}$ ñemongakuaa' literally means 'to make the child grow' and is used to refer to rearing practices. From Mbya perspective 'kakuaa' implies a progressive process towards understanding ('entendimiento').[5]

As noted above, Mbya parents state that it is no good for a child to become a weeping one ('llorón'). If children cry a lot and without any reason parents say they are 'caprichosos' or 'malitos' (impulsive, fussy, bad). They are becoming 'pochy' and 'calientes' (hot). Once baptized, children begin to be educated in 'pochy' control. After that, they will be in a condition to 'understand' what the elders teach them. It represents an important transition between life stages, bringing a change in children's status. In short, a greater control of 'pochy' means the child is acquiring 'understanding,' they are growing up according to cultural expectations.

If children become 'pochy' it is an evidence of an imbalance between their 'good spirit' (' $\tilde{e}$ 'e pora') and their 'bad spirit' ('ñe'e vai').[6] The first spirit, of divine origin, is sent by deities during the conception and, in some way, prefigures the personality and individual preferences. The second one 'grows' during life. It is an expression of bad habits, i.e. the influence of an 'imperfect way of living.' This alienates the individual from obtaining spiritual perfection, the supreme goal of the life trajectory (see Cadogan, 1997).

It is believed that there are several reasons why older children continually cry, are fussy and disobedient. One of them is due to their parents' violation of taboos that apply to newborn babies' parents. Being baptized with a wrong name or being caught by an evil spirit are other reasons for a weeping child. These children are at risk of dying if an Opyguã (traditional healer) does not find the child's right name or he does not bring back their 'good spirit.' As one Mbya father interviewed said:

because our God said 'he is Karai' and we then baptized as Vera. So, the child does not like his name, his spirit feels bad. [What happens to children that do not like their spiritual name?] They are weak, cry a lot, eat but do not grow up, that is how we realise. (Ma. G., man, Mbya village of Yvy Pytã)

Finally, a child cries a lot when he is caught by an illness called 'ojeo'kea' which means 'his head is split, broken' ('se le parte la cabecita'). This expression refers to a late closure of the frontal bones of 
the skull. Typical symptoms are irritation and crying. The etiology is associated with three main facts. One of them could be a stressful event before the child's birth, for example, the exposure to a loud noise that affects the child's ears and head. Another might be parents' violation of taboos while the child is 'new' ('pyta').[7] Lastly, this illness might be caused by an 'evil person,' meaning, a person who can inflict harm on others, mainly those who are vulnerable like newborn children. These people can damage by means of 'substances' or 'humors' emanating from their body. According to Cadogan (1965), babies are not always intentionally damaged.

In referring to children affected by this emanation, both the terms oye-ojea and oye-jharu are used (ojea: possibly Guarani version of 'ojear' or 'to eye, to view with attention' or, as will be seen, possibly derived from Spanish 'hoja', 'leaf, blade, sheet, pane' etc.) ... children become nervous and irritable, crying all the afternoon until sunset. In severe cases the seams of the skull do not knit, the fontanels distend owing to the excess of encephalorachydic fluid, the child becomes hydrocephalous, and idiocy or death may supervene ... The word ojeo is Spanish; o-yeojea is typical of Paraguayan Guarani, a mixture of this language and Spanish; they are probably connected with 'ojo' (eye); ojear (to frighten or startle game) but may also be derived from the Spanish 'hoja'.... that the seams of the skull do not knit and the bones separate 'because the bones of our skull consist of many hojas. (Cadogan, 1965, pp. 210-211)

In Mbya parents' words:

We [Mbya people] call oje o ke'a [What do children feel in their heads?] as if children cannot see well their eyes ache and they cry too. Cry, cry, and they cannot be at ease, they cannot sleep they cry a lot when this part of the head is open [She points to the child's head close to the front bone]. I don't know how you name this part [We say the fontanel] yes, that's right, the bone takes a long time to close, but if they are oje o ke'a. So it takes longer to close and medicines are necessary to cure them ... (R.C., woman, Mbya village of Ka'aguy Poty)

kiringue ñakanguachuramo, mitã omonguera iñaka ojeo [children have big heads, the baby has a heat on its head]. She [his mother] says that the baby has a heat on its head and from where the bone breaks [How do you call that illness?] akãguachu 'big head' in guarani is oje o ke'a. So the bone breaks in the middle and you can cure that with a plant, the skin of tuna, with cold water and with that you wash the child's head three times a day. Sometimes we become ill because of a noise ... we have to look after children. (F.N., woman, translated by H.N., man, Yvy Pytã)

From the Mbya perspective, infants and young children are viewed as being particularly vulnerable, especially in the first years of life, until they are baptized (Remorini, 2009). In this sense, parental ethnotheories stress the concept of young children's vulnerability and the need to help them to achieve and maintain an equilibrium in their behaviors by avoiding certain classes of emotional expressions considered negative and risky for their health and social competence.

The concern for their children's health is frequent and recurrent in Mbya parents' discourses where illness and death of children are signs of imbalance between 'teko achy' (the imperfect way of life) and 'teko pora' (good, true, that is, the perfect or true way of life) (Remorini, 2009). The influence of the 'imperfect way of living' on people is revealed in the manifestation of cholera and anger. This behavior is socially sanctionable but at the same time is classified as a pathological condition which limits the child's liability.

A healthy child is easily recognized by the absence of physical symptoms of distress and behavioral disorders like irritability, weakness, listlessness, and excitement. These states are expressed in the vernacular in categories such as 'ndojaveima' (hasn't found herself; is sad), 'pochy' (angry, aggressive), 'achĕramo' (weeping baby). As a consequence, '(s)he doesn't want to grow' ('ndokakuaa'), (s)he is undernourished ('ipiru I'), or doesn't stand up ('no levanta'), or doesn't walk ('ãi êy va'e') (see Cadogan, 1997). As I have said (Remorini, 2009) recurrence of illnesses in a child and the existence of numerous sick children in a community are interpreted as a sign that 'something is wrong' at community level. If the child's spirit 'doesn't find itself ('no se halla' or 'ndojaveima') it is because the living conditions of the 'teko' $a$ ' (community) are not adequate to ensure children's growth and well-being. 


\section{Creole Population in Calchaqui Valleys}

Molinos Department is in Calchaquí Valleys of Northwest Argentina (see Figure 2). The Calchaquí Valleys have been continually peopled for over 2500 years. In the area inhabited by indigenous peoples called 'diaguita' or 'calchaqui,' who spoke the 'kakan' language, some groups speaking 'quechua' - coming from the Inca expansion - settled in the fifteenth century. This resulted in a certain homogeneity in cultural patterns and practices common to all the Andean region. The present population represents from the cultural point of view a mixture of indigenous and hispanic elements. Most people define themselves as 'criollos' (creoles). Most are Catholic, the Church being a highly significant institution in community life, even though they continue to believe in 'Pachamama' and other deities and supernatural agents and engage in rituals related to them.

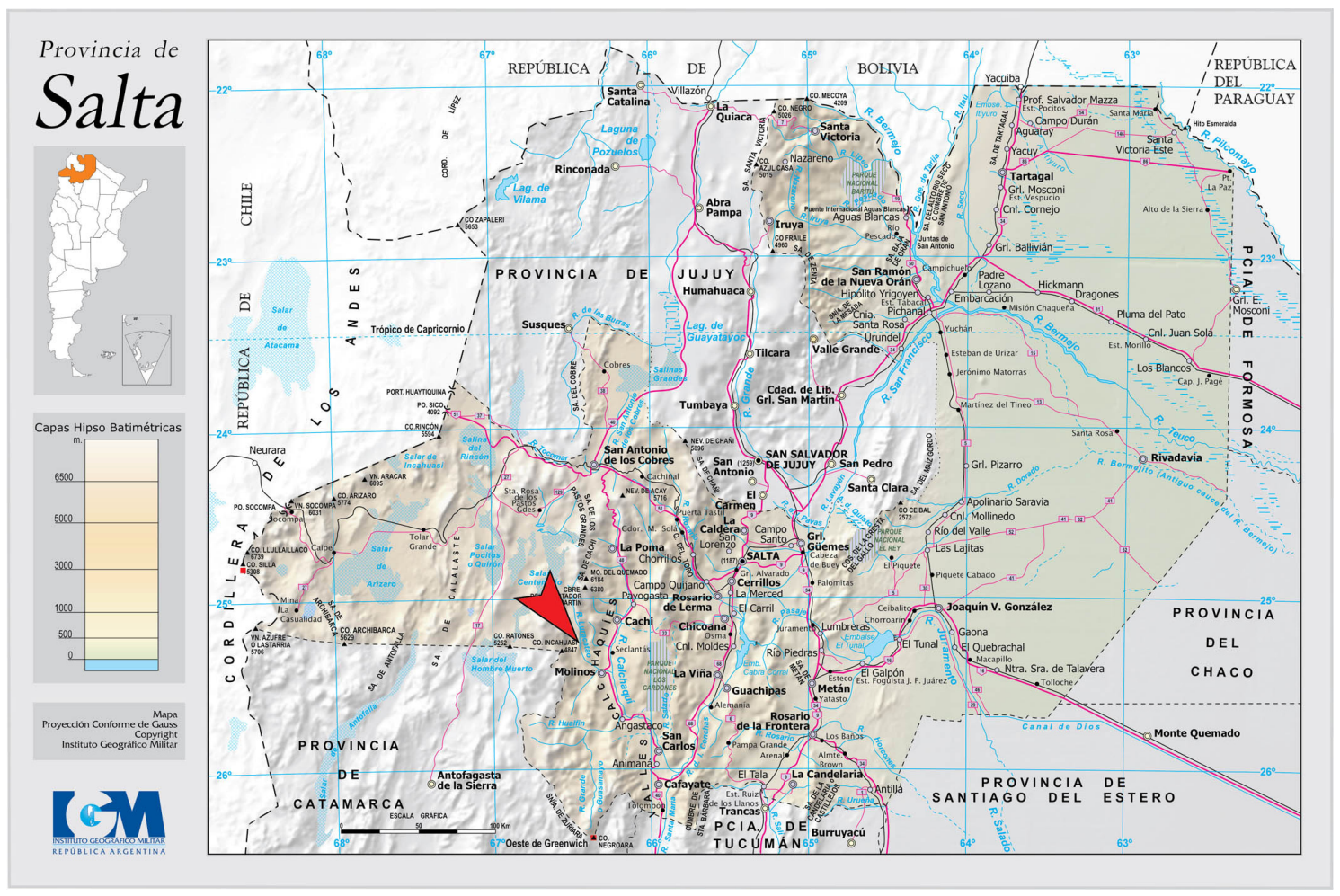

Figure 2. Molinos Department (Salta province).

According to an official census made in 2009, there are 2494 people living in Molinos Department. The present economy is based on vast farm production, cattle breeding and domestic farming for self-consumption. Although some people are still performing those activities, young people are mainly engaged in other tasks such as commerce, wage-earning jobs - both inside and outside Molinos - or even state administrative jobs and, to a lesser degree, professional or technical practice at hospitals or schools. Tourism is at present an important source of income which, in turn, increases textile activity and the transformation of old buildings into multi-service hotels.

The displacement generated by outside economic activities results in some cases in a household structure where adult or elderly women take the family leadership and the responsibility for their grandchildren's rearing. Different from Mbya communities, there exists in Molinos a greater diversity in household composition. This depends on the father's job and where the houses are located (i.e. in the centre of the village, its outskirts or on the hills). Men, in general, do not participate actively in childrearing, this being an almost exclusively feminine activity. Elder siblings are not usually responsible for the caring of the younger ones. Younger children spend most of their time with their mothers or playing alone. In this regard, another difference with Mbya communities is the larger spatial segregation between child and adult activities. 
Although currently more people attend the hospital and sanitary posts, some illnesses such as fright - which will be later described - are still being cured in the domestic realm, or else by consulting traditional healers ('médicos campesinos') because biomedicine is not considered able to diagnose and treat them.

\section{Molinos Parents' Attitudes toward Crying}

Different from adults from Mbya communities, Molinos parents tend to have less tolerance for a crying infant. When a baby cries, they try to calm it immediately usually by breastfeeding the child, talking to it or rocking it in their arms. But if it is an older child, they disapprove of its weeping and scold it.

According to local ethnotheories about childrearing 'guaguas' (children) are supposed to be 'good' ('buenito'), obedient and quiet. 'Guagua' is the term that refers to younger children in Andean cultures and is associated with affection, protection and innocence (Arteaga \& Dominic, 2007). It implies that babies should be protected and cared for not only by parents but also by the whole community. Following Arteaga and Dominic (2007), relationships between guaguas and their families are mediated by the idea of affection and reciprocity. This means that parents should rear children with affection, care for them while they are young and vulnerable, but at the same time, children should behave similarly to their parents. That is, not only give them affection, but also collaborate with them, be obedient and when they are older, protect and nurture them.

Molinos parents prefer their guaguas to be quiet and silent. If babies, they should allow their mothers to perform their activities without upsetting them. Mothers usually complain about weeping children ('llorones') because they say they are difficult to rear, do not allow their mothers to work and cannot be left in the care of other members of the family. Children are taught early to collaborate in several domestic tasks and adjust their behavior to domestic routines.

These references about how young children should behave must be understood in close relation with what is thought to be right for an adult in their society. In this respect, mothers and grandmothers stressed during the interviews the importance of being 'fuertes' (strong) and 'tener coraje' (be brave) to face different problems during the life course. In this sense, children's autonomy together with their obedience and responsibility are strongly valued.

\section{Molinos Parents' Ethnotheories about Children's Crying and Vulnerability}

Taking into account how Molinos parents perceive and evaluate their children's emotional behavior I focus now on the ideas regarding crying as a pathological symptom. Molinos people argue that when infants and young children cry too often they could be 'frightened' ('asustado'). 'Susto' is a very common ailment throughout the Andean area, whose origin is associated with a traumatic, unexpected or stressful experience or event, e.g. if the child is dropped or struck, has seen or been attacked by an animal (such as a snake, chicken, or dog), or heard the loud sound of thunder or wind.

Children are considered especially vulnerable to suffering 'susto.' This ailment involves the temporary loss of a person's soul. The origin of 'susto' is based on a widespread conception that an individual consists of a body and of an immaterial substance, an essence which can separate itself from the body, wander around freely, or else remain captive from supernatural forces ('te agarra la tierra/la puna'). This immaterial substance (soul or 'espiritu') is separated from the body as a consequence of a stressful or scary experience and then the person becomes 'asustado.' Besides the frequent weeping, the main symptoms in children are insomnia, nervousness and weakness (Remorini et al, 2010).

Some women state that they should be attentive to their children all the time, paying close attention to who they are with and where they wander around to avoid having them be frightened.

Children could also become 'asustados' if their mothers when pregnant were exposed to situations or places related to death. Situations like passing by cemeteries, attending funerals or 'antigales' (places where ancestors are buried) or being near dead people make women liable to exposing their children to 'susto'. So the baby will be born 'aicado'. This term designates the child who suffers from 'aique' and is derived from the kechuan term 'aykkey' (to flee, to run away, to 
escape) (Crivos et al, 2008). In these cases, children show slow growth, undernourishment and suffer diarrhoea frequently. In our informants' words:

[The aicado child is the one] that has problems to improve, to grow, to gain weight ... he has diarrhoea; during pregnancy it occurs, there, in the belly, babies become aicado, and they are very thin, undernourished. (N.R., woman, Molinos)

Finally, people make reference to 'quedao,' designating those individuals affected by particularly serious forms of 'susto', or who were not cured from the illness in time. People affected - when children or adults - show developmental problems which could cause varying degrees of disabilities, like stammering and deafness. Children cry a lot and too often which makes rearing difficult.

doctors ['médicos campesinos'] always told me that I suffered a lot when I was pregnant, it is true, I always cry a lot because he was afraid of everything, as long as I kept crying ... they told me Milton is in this way because of that ... his deafness, and they told me it was because I suffered from fright, and at that time I didn't recover. (P.C., woman, Molinos)

Inhabitants never visit to biomedical professionals for 'susto' diagnosis and treatment but turn to traditional medicine, because physicians 'don't know how to deal with asustados.' Only 'médicos campesinos' (traditional healers) can diagnose and cure 'susto,' by retrieving the lost spirit ('llamado' or call of spirit) using different procedures which express the syncretism between Catholic and indigenous knowledge, practices and resources (Remorini et al, 2010). Although 'fright' is a very frequent illness during infancy, its more serious expressions ('aicado' and 'quedao') generate parents' concern. They not only reveal the inefficiency of the given treatment but also imply long-term consequences for children's health and social competence.

\section{Summary and Conclusions}

Emotions are an essential aspect of human nature. They represent a significant part of our biological and cultural heritage and our adaptation to the environment. Emotions also play a critical role in enhancing human interactions and caring activities throughout the life span (Izard, 2002). They have an important impact on caregivers' attitudes toward children and the quality of care given to them (Harkness \& Super, 1994). This article has aimed to describe some of the ways in which children's emotional experiences are decoded by cultural beliefs and shaped by rearing practices in two different contexts.

The basis of this article is an interest not only in caregivers' daily attitudes but also in their discourse about childhood and childrearing, as both constitute a central component of the developmental niche. Particularly, I focused on the way childrearing discourse 'constitutes' (Murphy, 2007) healthy and socially competent children. Following Jenks (1996), concepts of childhood and of the child are not neutral, objective, natural 'givens' but impregnated with theoretical assumptions. In this sense "children and childhood are formed, "made up" or constituted through these theory-impregnated forms of discourse' (Murphy, 2007, p. 105). I include within these 'theoretical' frameworks the common sense and shared 'typifications,' some of which take the form of 'parental ethnotheories.' These ethnotheories, far from being homogeneous, exhibit tensions because of the impact of intergenerational changes and the contribution of professional and institutional discourses. In this sense I focused on how parents discourses of childhood in each ecological context validate some expressions of emotion and restrict and pathologize others. This focus included analysis of the knowledge and values about appropriate or inappropriate emotional behaviors and their implications for achieving the goals of parenting.

These findings suggest that there exist similarities in the way in which parents in the Mbya and Molinos communities perceive their children's crying, but there are differences regarding the characteristics of each developmental niche. In both communities, parental ethnotheories about crying are related to the idea that infants' and young children's vulnerability justify the need to avoid certain extreme and risky behaviors such as senseless crying. It is expected that children become aware of their behavior and learn, at an early age, to control emotions like weeping and anger, because they are considered a risk for children's health and their social competence. In other words, they are non-adaptative behaviors in this developmental niche. 
In both groups, there is a threshold above which crying is viewed as evidence of a pathological condition. When parents interpret their babies' crying as the reflection of genuine need or as a symptom of illness, they do not view such behavior as illegitimate. According to Murphy (2007):

As sociologists of deviance have long argued, the designation of an action as deviant or otherwise does not depend upon the outcome of that action. Rather, like childhood, deviance is socially constructed and depends upon the interpretation of the action in question. It is only where an action is deemed both avoidable and intentional that it is likely to be treated as illegitimate. (Murphy, 2007, p. 123)

In both ecological contexts adults view infants as being particularly vulnerable and at risk of a number of illnesses. Cultural ideas about children's vulnerability in the first years of life are consistent with biologically based growth and development and the fact that the infant is at greater risk of illness and death. These ideas have effects on the structure of the caretaking environment as cross-cultural research on child development has demonstrated (Harkness \& Super, 1994; Cervera \& Méndez, 2006).

Regarding this, I agree with Gaskings (2000) when she states that cultural understandings about the nature of the world and about the nature of children significantly shape children's experiences. In this sense, parents' health concerns lead to specific limitations on the child's activities, with the aim of ensuring the child's well-being. For example, children should avoid certain places at given hours, stay close to their mothers, and avoid being in contact with animals, among others.

The research team recorded more concern about the infant's health in the case of Mbya parents, as it is expressed in their discourses and protection measures when children are cared for. Crying and extreme behaviors are seen as having consequences not only for the child but also at social and cosmological levels. In relation to this, in Mbya communities, above-mentioned illnesses are usually considered parents' responsibility. Their etiology is associated with parents' violation of moral taboos and rules imposed during 'the times of the ancestors' (Remorini, 2009).

Molinos parents believe that 'susto' etiology is wider and ambiguous, including the influence of other people, animals, supernatural entities and several environmental hazards. Although people from Molinos still believe in 'susto' and other culturally bounded illnesses, younger mothers' discourse exhibits greater influence of the biomedical discourse about risks in childhood. At the same time, they admit they have abandoned some 'traditional' practices and beliefs. On the other hand, Mbya parents' discourses exhibit greater commitment to the moral precepts and practices considered 'traditional' and rooted in the Guarani way of life.

Appropriate behavior is defined in each context with regard to cultural expectations related to adult-children interactions, children's contribution to domestic chores and children's well-being. Besides health problems, mothers emphasized difficulties in rearing weeping children and expressed their concern about consequences of this behavior in later social skills and competence. However, this concern seems to be more significant in Molinos communities. Similarly to Gaskings' (2000) description of everyday activities in a Yucatec Mayan community, in Molinos, we recognized that children's care and their daily activities are primarily structured by adults' work. One of the chief complaints about crying children is that they interfere with mothers' work. Children should be quiet and learn to collaborate on domestic tasks.

In this sense, the results are consistent with studies of other Latin American indigenous societies (see for example Gaskings, 2000; De León, 2003; Rogoff et al, 2003; Cervera \& Méndez, 2006):

children who are chechones ('llorones') and have 'malos modos' (bad ways) are perceived as more difficult to care for ... may contribute to the later emergence of stubbornness and disobedience if parents do not correct their children. ... Mothers expect children to better understand their surroundings and moderate or change their behaviors as they develop ... Adapting to multiple caregivers or to being left alone are relevant to mothers, otherwise they are not able to do household chores. (Cervera \& Méndez, 2006, p. 334)

According to our observations of daily activities and conversations, children's activities, desires and general development in Molinos communities, receive less attention compared to Mbya 
communities. Mbya mothers spend most of their time in caring for their infants, and fewer domestic tasks are expected from them. We observed high maternal attentiveness to children's needs and demands even when they interfered with their own activities. As has been said before, this situation changes when children start to walk. Gradually, the infant learns to get along with everyone in the household and responsibility for childcare is shared.

In summary, this study suggests that parental ethnotheories provide a general framework for understanding beliefs about and responses to children's emotional behaviors. Caregivers attempt to organize physical and social settings for children that are consistent with their own ethnotheories. In this sense, I agree with Harkness and Super's (1994) suggestion that ethnotheories play a major role in creating the child's developmental niche.

This preliminary analysis of this subject leads to a recognition of the value of ethnographic study of socialization of emotions through observations of everyday life and records of parents' discourse. At the same time, a detailed and comparative analysis of adult-child and child-child interactions is not included in this article, nor is the mutual regulation of expression of emotions within these interactions. This would widen our understanding of the process of socialization of emotions in each context. These issues might be dealt with in the future. Despite the abovementioned limitations, I believe this article, though preliminary, represents a contribution to ethnographic knowledge about childhood and child development, as there are few studies on this topic in the regions considered.

\section{Acknowledgments}

This research was supported by the National University of La Plata and the National Council of Scientific and Technological Research (CONICET). I want to thank all members of both populations for their cooperation and warm hospitality during our fieldwork. I wish to dedicate this work to all people who shared their knowledge with me and especially to the children of both communities because, since my ethnographic work with them, I understand the importance of ethnography in the study of child development. Finally, I want to thank my teacher Graciela Britch for helping me with the manuscript and special thanks to the reviewers for their comments and invaluable contributions to the final version of this article.

\section{Notes}

[1] We could not interview men since they tend to be away from home much of the day due to work.

[2] The tung (Vernicia fordii) is a tree of the Euphorbiaceae family grown in northeastern Argentina, a source of industrial oil.

[3] Mba'e Pochy: the origin of evil (Cadogan, 1992, p. 104).

[4] Being a 'Mbya' is a status that is not achieved by birth but only when the personal name (sacred name) is given to the child. One of the most important transitions in the life course, which allows children to become persons, is the name-giving ceremony called Nemongarai, also referred as 'baptism.' The Nemongarai ceremony occurs around the second year of life. Only when children can stand up, walk, speak some words and 'understand their name' are they ready to receive their 'sacred name,' i.e. the name of their soul/spirit (ñe'e). For more details see Remorini (2009).

[5] In Mbya language, Kakuaa also means 'to know, to understand' (Cadogan, 1992). In this sense, a mature child is one who has achieved 'understanding.'

[6] Human life (teko) begins when the human spirit or soul (ñe'e), sent by one of the four gods (Ñe'e Ru Ete: 'the true fathers of our souls') 'sits down' (oñemboapyka) in the woman's uterus at conception. When children are conceived they acquire their name but it is discovered in the Nemongarai. In this ceremony the Opyguã discovers the origin of the child's soul (their father). It is important because the person's abilities, skills, preferences and future social roles are based on their soul's origin. A Mbya person consists of, at first, a spirit/name (ñe'e) and a body (hete), each with different origins, divine and human, closely related, their dissociation being a sign of disease or death. Throughout the life cycle, another soul, of animal origin, not divine, is added to the person. This soul is responsible for undesirable behaviors that prevent humans from achieving spiritual perfection. (For more details see Cadogan, 1997; Remorini, 2009). 
[7] In Mbya Guarani language newborn children and those in their first two months of life are called ava pyta i and kuña pyta i (boys and girls respectively). Pyta means 'new.' 'Mitãi' is the term used to refer to breastfed children from two months to the age of four to five (after that they are called 'mitã).

\section{References}

Arteaga, A.C. \& Dominic, J. (2007) Ser wawa en los Andes: Representación social de mujeres migrantes aymaras sobre el niño (a) aymara [Electronic version], Ajayu, 5(1), 1-26.

Bateson, G. \& Mead, M. (1942) Balinese Character: a photographic analysis. New York: New York Academy of Sciences.

Bronfenbrenner, U. (1987) La ecología del desarrollo humano: Experimentos en entornos naturales y diseñados. Barcelona: Paidós.

Cadogan, L. (1965) En torno al Bai Ete-Ri-Va guayakí y el concepto guaraní de nombre, Suplemento Antropológico, 1(1), 3-13.

Cadogan, L. (1992) Diccionario Mbyá-Guaraní-Castellano. Asuncion, Paraguay: Biblioteca Paraguaya de Antropología.

Cadogan, L. (1997) Ayvu Rapyta- Textos Míticos de los Mbyá-Guaraní del Guairá. Asuncion, Paraguay: Biblioteca Paraguaya de Antropología.

Cervera, M.D. \& Méndez, R.M. (2006) Temperament and Ecological Context among Yucatec Mayan Children, International Journal of Behavioral Development, 30, 326-337. http: / / dx.doi.org/ 10.1177/0165025406072794

Crivos, M., Martínez, M.R. \& Pochettino, M.L. (2008) Phytotherapy Applied to the Treatment of Cultural Bound Syndromes in Calchaqui Valley (Salta, Argentina), in D. Thangadurai (Ed.) Medicinal and Aromatic Plants. New Delhi: Regency Publications.

Daltabuit Godás, M. (1992) Mujeres Mayas: Trabajo, nutrición y fecundidad. Mexico: Instituto de Investigaciones Antropológicas.

De Assis, V. \& Garlet, I. (2004) Análise sobre as populações guarani contemporâneas: Demografia, espacialidade e questõs fundiárias, Revista de Indias, 64(230), 35-54.

De León, L. (2003) Ta xtal xa xch'ulel: 'Ya viene el alma'. El miedo en la socialización zinacanteca, in B. Alain, M.B. Aurore \& R.M. Humberto (Eds) Espacios mayas: Representaciones, usos, creencias. Mexico, DF: Centro de Estudios Mayas, IIFL-UNAM and Centro Francés de Estudios Mexicanos y Centroamericanos.

Efron, D. (1972) Gesture, Race and Culture. La Haya, Paris: Mouton.

Elder, G.H. Jr (1998) The Life Course as Developmental Theory, Child Development, 69, 1-12.

Gaskings, S. (2000) Children's Daily Activities in a Mayan Village: a culturally grounded description, CrossCultural Research, 34, 375-389. http: / / dx.doi.org/10.1177/ 106939710003400405

Gauvain, M. (1998) Cognitive Development in Social and Cultural Context, Current Directions in Psychological Sciences, 7, 188-192. http:/ / dx.doi.org/10.1111/1467-8721.ep10836917

Greenfield, P., Keller, H., Fuligni, A. \& Maynard, A. (2003) Cultural Pathways through Universal Development, Annual Review of Psychology, 54, 461-490. http: / / dx.doi.org/10.1146/annurev.psych.54.101601.145221

Harkness, S. \& Super, C. (1986) The Developmental Niche: a conceptualization at the interface of child and culture, International Journal of Behavioral Development, 9, 545-569.

Harkness, S. \& Super, C. (1994) The Developmental Niche: a theoretical framework for analyzing the household production of health, Social Science and Medicine, 38(2), 217-226. http: / / dx.doi.org/10.1016/0277-9536(94)90391-3

Ingold, T. (2000) The Perception of the Environment: essays on livelihood, dwelling and skill. London: Routledge. http: / / dx.doi.org/10.4324/9780203466025

Instituto Nacional de Estadística y Censos, Argentina, Provincia de Misiones (n.d.) Encuesta complementaria de pueblos indigenas (ECPI) 2004-2005. http: / / www.indec.gov.ar

Izard, C. (2002) Translating Emotion Theory and Research into Preventive interventions, Psychological Bulletin, 128(5), 796-824. http:/ / dx.doi.org/10.1037/0033-2909.128.5.796

Jenks, C. (1996) Childhood. London: Routledge.

Larricq, M. (1993) Ipytuma: Construcción de la persona entre los Mbyá-Guarani. Posadas: Universidad Nacional de Misiones. 
Malinowski, B. (1964) El problema del significado en las lenguas primitivas, in C.K. Ogden \& L.A. Richards (Eds) El significado del Significado. Una investigación acerca de la influencia del lenguaje sobre el pensamiento y de la ciencia simbólica. Buenos Aires: Paidos básica.

Martínez, M.R., Crivos, M. \& Remorini, C. (2002) Etnografía de la vejez en comunidades Mbya-Guaraní, provincia de Misiones, Argentina, in A. Guerci \& S. Consigliere (Eds) Il Vecchio allo Specchio: Vivere e curare la vecchiaia nel mondo, vol. 4. Génova: Erga Edizione.

Mauss, M. (1968) L'expression oligatoire des sentiments, in Essais de sociologie. Paris: Seuil

Mauss, M. (1971) El concepto de técnica corporal, in Sociología y Antropología. Madrid: Tecnos.

Mead, M. (1954) The Swaddling Hypothesis: its reception, American Anthropologist, 56, 395-409. http: / / dx.doi.org/10.1525/aa.1954.56.3.02a00090

Mead, M. (1962) Educación y Cultura. Barcelona: Ed. Paidós.

Mead, M. (1990) Sexo y Temperamento en tres sociedades primitivas. Mexico: Paidós Studio.

Murphy, E. (2007) Images of Childhood in Mothers' Accounts of Contemporary Childrearing, Childhood, 14(1), 105-127. http:/ / dx.doi.org/10.1177/0907568207072534

Remorini, C. (2001) Caminar a través del monte. Una aproximación a la movilidad Mbyá en el pasado y en el presente, in Proceedings II jornadas sobre poblamiento, colonización e inmigración en misiones, pp. 309-326. Posadas: Ediciones Montoya.

Remorini, C. (2009) Aporte a la caracterización etnográfica de los procesos de salud-enfermedad en las primeras etapas del ciclo vital. La Plata, Argentina: Comunidades Mbya-Guaraní de Misiones.

Remorini, C. (2010) Crecer en movimiento: Abordaje etnográfico de la crianza y el desarrollo infantil en comunidades Mbya (Argentina), Revista Latinoamericana de Ciencias Sociales sobre Niñez y Juventud, 8(2), 961-980.

Remorini, C., Crivos, M., Martínez, M.R. \& Aguilar Contreras, A. (2010) El 'susto': 'Síndrome culturalmente específico' en contextos pluriculturales. Algunas consideraciones sobre su etiología y terapéutica en México y Argentina, in M.L. Pochettino, A.H. Ladio \& P.M. Arenas (Eds) Tradiciones y transformaciones en Etnobotánica: proceedings of ICEB 2009, pp. 523-530. San Salvador de Jujuy, Argentina: CYTED.

Rogoff, B., Paradise, R., Mejía Arauz, R., Correa-Chávez, M. \& Angelillo, C. (2003) Firsthand Learning through Intent Participation, Annual Review of Psychology, 54(1), 175-203.

http:/ / dx.doi.org/10.1146/annurev.psych.54.101601.145118

Solis-Cámara, P. \& Romero, M.D. (2007) Relaciones entre creencias y prácticas de crianza de padres con niños pequeños, Anales de Psicología, 23(2), 177-184.

Weisner, T. (1984) Ecocultural Niches of Middle Childhood: a cross-cultural perspective, in A. Collins (Ed.) Development during Middle Childhood, pp. 335-369. Washington: National Academy Press.

Weisner, T. (1996) Why Ethnography Should Be the Most Important Method in the Study of Human Development, in R. Jessor, A. Colby \& R. Shweder (Eds) Ethnography and Human Development, pp. 305-324. Chicago: University of Chicago Press.

Whiting, B. \& Whiting, J. (1975) Children of Six Cultures: a psycho-cultural analysis. Cambridge, MA: Harvard University Press.

CAROLINA REMORINI is a researcher at the National Council of Scientific and Technical Research (CONICET), and professor of the courses of American and Argentinian Ethnography in the Department of Anthropology of the Faculty of Natural Sciences (UNLP) at the National University of La Plata, Argentina. She researches childrearing practices and their relationship with children's health and development from an ecological perspective in native and rural populations of the northwest and northeast of Argentina. Correspondence: cremorini@yahoo.com.ar 